\title{
Changing of Political Identities within the Globalization Context
}

\author{
Hao Zhang
}

\begin{abstract}
Political identity is always a vital topic for scholars to discuss, especially within the globalization context. Anderson has given a famous notion of identity, however, due to the globalization process, the sense of limitation and sovereign has been eroded, and Anderson's notion has been challenged. This essay has explored the changing of political identities, with the cases of Canada and Turkey. Owing to the influence of globalization on many significant factors, such as language, culture, economic factors, the political identity is no longer restricted to the territorial limitation. Homogenization and democratization and some other factors have played a role to shape the political identity.
\end{abstract}

Index Terms-Democratization, homogenization, political identity.

\section{INTRODUCTION}

It is always a crucial topic to discuss issues related to identities. Just as Bruter has referred that by identifying themselves to the community, citizens give their legitimacy to political community for reaching their wills [1]. In contrast, "without identity, it seems that there can be no true, durable, legitimacy attached to a political entity, no conscious acceptance of the power of the state and of its monopolistic right to use legitimate coercion" [1]. As Bruter has defined that identity could be separated from two forms, that is, personal identity and social identity [1]. Personal identity is a series of sense of personal background, personal characteristics and characteristics of the belonging culture. While social identity is in reference to those feelings and characteristics by which the difference could be made and therefore identity could be marked out by the difference.

Bruter has argued that some scholars have studied the political identity just as it is the extension of the individual's social identity [1]. However, Bruter has indicated that the political identity involves both the personal and social factors and could not be reduced to only one component [1]. By Smith's statement, the perspective of political identity could be considered as "a set of characteristics by which persons are recognized by political actors as members of political group. There are many sources of such recognition, such as party affiliation, nation-state membership, ethnicity, economic status, language, and others" [2].

Fletcher has inferred that as the "emergence of transnational communication systems and a worldwide free market in cultural products", globalization has elicited many

Manuscript received August 19, 2013; revised October 21, 2013.

Hao Zhang is with the Social Sciences in China Press, Room 1103, Taida Building, Chaoyang District, Beijing, 100026, China (e-mail: iris_zhanghao@hotmail.com). political issues [3]

Anderson has given a famous notion of nation as "an imagined political community - and imagined as both inherently limited and sovereign" [4]. However, Albrow has argued that the sense of limitation and sovereign has been eroded in the globalization era, within which "peoples of the world are incorporated into a single world society, global society" [5]. Accordingly, the conception of political community has been changed within the context of globalization, thus, identity has been changed. Moreover, Held has explained that "globalization is neither a singular condition nor a linear process. Rather, it is best thought of as a multidimensional phenomenon involving diverse domains of activity and interaction, including the economic, political, technological, military, legal, cultural and environmental" [6], which activities and interactions are core elements of recognized source of political identity as Smith mentioned. Therefore, the globalization has vital impacts on political identity both on its concept and components.

This essay will discuss the changing of political identities within the context of globalization, especially from the cultural and political aspects. Firstly, some general argument about the changing of political identity in the globalization context will be explored. Secondly, a case of Canada will be analysed. In this part, the changing of political identity in the cultural aspect will be mainly examined. Thirdly, a case of Turkey will be studied. In this part, the changing of political identity will be examined mainly in the respect of political aspect.

\section{Political Identity in the ERA OF Globalization}

\section{A. General Ideas about Political Identity Changing}

Scholte has asserted that globalization is a circumstance in which social relations and interactions happened with less territorial limitation [7]. In this sense, Kosebalaban has suggested that, globalization has created the condition in which international relations and societal forces could interact within nations and on the global scale [8]. In this respect, people's horizons have been broadened, by which people may make new consciousness of their political communities and social standards, in that, their political identities may be changed.

Woodward has argued that by the essential approach, identities have been regarded as fixed and nature-based, however, new shared identities have been produced by the interaction among political and social factors in the globalization wave, whereby many changes have been taken place in a variety of fields, such as in the cultural and economic field [9]. 
By the reason of cultural convergence and cultural homogeneity of the global marketing, Woodward has pointed out that new identities have been detached from community and social status [9]. For instance, Woodward has mentioned that global consumers are indistinguishable, such as MacDonald-eating and walkman-wearing [9].

Moreover, Woodward has also suggested that the large scale of migration is closely related to globalization, and it has caused changes in the global economy and in the structure of labour market [9]. In this sense, not only has the global consumption created the new identities, but also the increasing international migration in globalization era has shaped the identities of societies and politics all around the world.

Furthermore, due to the limitations of territory and sovereign are less influential than how they were in the pre-globalization era, Woodward has challenged the imagined community conception of political identity, which conception is addressed to describe the identification of nation and stress the shared unified and homogenous national culture [9]. Therefore, it is hard for the political identity to always maintain the same under the globalization circumstance.

\section{B. Political Identity Changing with the Case of Canada}

Herder has mentioned that language and culture are the most important components of a nation and its people's political identities [10]. Furthermore, Herder has indicated that identities are only existing in the interpretation account, which account is constituted by the language and culture [10] Moreover, people may be aware of the insider and outsider by the language and cultural symbols [10]. Poole has inferred that identities are formed form "most of human history, the cultural and linguistic horizons of the vast majority of people", in which horizons people are restricted to the territorial limitation [11]. In this respect, the base of the shared identity of belonging to the particular region and community is provided by the language and culture.

However, under the circumstance of globalization, identities has no longer been restricted by the territorial limitation, but rather has been altered because of the impact of globalization on language and culture. The change and challenge of the Canadian identity could illustrate this point of view well.

Due to the colonising, the aboriginal Canadian identity has been transformed, and ascribing to the open immigration policy, it has become multicultural society in Canada. Since 1760s, Canadian has experienced the bicultural nature, the English-French culture. Now Canada is a country with two different communication systems, the English and the French.

Fletcher has suggested that the Canadian has suffered the identity crisis, because of the erosion of the origin political identity, which is affected by the globalization [3]. Additionally, there is an increasing in the media conglomerate on the global scale, which has altered the global cultural market, and the rapid emergence of new communication techniques has increased the flow of imported goods and could not be rejected. In this sense, the political identity has been affected and changed as well as culture, because of the imported consumption materials.

To support this point of view, Balthazar has suggested that Canada is always exposed to global cultural influences, owing to short of a unifying myth [12]. Moreover, Charland has stated that the "Canadian communications policy has been characterized as the development of a communications network without nationhood, a technological achievement without vision" [13]. In this respect, Fletcher has regarded Canada as an empty nation, so that its public space has been filled in much of imported elements, and its people lack of a common shared distinctive political identity [3].

For instance, Fletcher has compared the identity of francophone and anglophone in Canada, it is evident that the English-speaking culture and identity are more vulnerable to globalization influences, owing to which language is a kind of universal language [3]. For illustration, it has been calculated that only less than $20 \%$ of domestic English cultural market are dominated by the Canadian producer, while the average share in other industrialized countries is about $80 \%$ [14]. Although both the francophone and anglophone have consumed much American cultural products, the French-speaking Canadian could see the reflection of themselves and identify that these cultural products comes from external, while, the English-speaking Canadian has seen mostly Americans and could not distinguish themselves from the American. In this respect, the English-speaking Canadian has no longer traced their history, but rather changing their political identities to adjust to the globalization wave [3].

\section{Political Identity Changing with the Case of Turkey}

Falk has stated that democratization has not affected the much of Islamic world, even though it has swept Eastern Europe [15]. The global decision making process is lack of Muslims, even if the decision would affect them directly.

Kosebalaban has indicated that "Islamic identity has emerged as the vocabulary to express an anger in the Islamic world rooted in structural factors" [8]. However, the anger might be eased by globalization, in which the channel of participation of social mobilization could be opened.

Kosebalaban has compared the Turkish identity before and after 1990s. He has suggested that before 1990s, Turkey Islamists was "largely used confrontational rhetoric in describing Turkey's position vis-à-vis the West", while following the 1990s, there is a considerable change that Turkey has become more "globalist outlook" and begun to state its position both within the international and domestic political systems [8].

Scholars, like Dagi, have held the point that from the liberal political worldview, Islamist identity could not be transformed but could be completely abandoned [16]. While, Kosebalaban has argued that it could not be neglected that the Islamic social and political orientation has still been maintained, rather than been abandoned [8]. Furthermore, identities in Turkey are suffering the ongoing changing process, in which Turkish world vision has been changed.

When specifying these points of identity changing in Turkey, Kosebalaban has stressed the crucial impact of globalization and European Union on Turkey [8]. Kosebalaban has suggested that in the past political scholars 
in Islamic world has regarded the Western world and the European Union as a "Christian Club", while now the Turkish is slowly accepting and integrating with Western institutions. Kosebalaban has cited Erdogan's statement that it is impossible to reverse the trend of globalization, in that, Turkey needs to benefit from the globalization trend by adopting the European values in particular fields, such as human rights, secularism and freedom of thought [8], [17]. Additionally, "the process of European integration has provided Turkey with a frame of democratization" and significant changes of identities in political, economic and social reforms have been made, which would be not assumable without the motivation of globalization and European integration [8].

Besides the influence on the political identity of Turkey in the national perspective, globalization also has important impact on individuals. It is suggested by Kosebalaban that the repressive state system does not encourage its people to participate in social mobilization and does not allow criticism of domestic system [8]. However, globalization has rapidly provided individuals, who live under the extremely closed regimes, the chance to interact with others on the global scale. In other words, globalization has entitled people, who live in the highly repressed political systems, to express themselves on global level, by creating a borderless world and giving people the access to influential global communication [8]. To support this point of view, Kosebalaban has provided an example that "on February 28, 1997, the Turkish military in alliance with TUSIAD, the media, and other secular NGOs initiated a soft coup in the form of pressuring Prime Minister Erbakan to resign", and following the event, the Turkish government has forced people such as by limitating the cultural expression [8]. While, these restrictions forced by the state has persuaded people to seek the "opportunity spaces" in the global sense, and people have found that globalization has presented this kind of opportunity which has been rejected by the domestic. In this sense, the state's attempt does not work in facing to globalization. As Kosebalaban has illustrated that some capital groups has started to invest in the international markets, and headscarf-wearing students have gone to overseas for education [8]. In this respect, globalization has aggravated the effect of political, economic and cultural modernization, in which political identities are enduring the ongoing changing process.

\section{CONCLUSION}

This essay has explored the changing of political identity in the era of globalization. It is suggested that there are many crucial factors of political identity, such as language, culture, social and economic factors. Owing to the influence of globalization on these vital factors, it is argued that the political identity has been altered within the context of globalization.

The political identity is used to restricted by territorial and cultural limitations of the "imagined community", while globalization has created a supraterritorial world and empowered the societal force for international interactions on the global scale. Politically, cultures and ideas have been disseminated across borders by the international interactions of globalization.

One of the influential phenomena of globalization is the homogenization. The Canada case has illustrated that people's political identities have been altered and been ambiguous, especially those people who are vulnerable to the cultural convergence, such as English-speaking people.

Democratization and human right are the other two important factors of globalization. The Turkey case has illustrated that people could find the way to express themselves on the global level by the condition provided by globalization, which enables people to access the global communication. This condition is much crucial for people who live under a repressive and closed regime to broaden their horizons and change their identities. Moreover, to participate in the international interactions would also help the repressive nation to process its democratization and construct the new political identity.

In this sense, no matter the country is an industrial country or is a repressive country, political identities of the country have been changed due to the globalization impact on factors, such as culture, social, political and economic.

\section{REFERENCES}

[1] M. Bruter, Citizens of Europe: The Emergence of Mass European Identity, London: Palgrave, 2004, pp. 2-10.

[2] R. M. Smith, "Identities, interests, and the future of political science," Perspectives on Politics, vol. 2, no. 2, pp. 301-312, June 2004.

[3] F. J. Fletcher. (1998). Media and political identity: Canada and Quebec in the era of globalization. Canadian Journal of Communication. [Online]. 23(3). Available: http://www.cjc-online.ca/index.php/journal/article/view/1049/955

[4] B. Anderson, Imagined Communities, (New Edition), London: Verso, 2006, pp. 6.

[5] M. Albrow, Globalization and Society, California: Sage, 1990, pp. 7.

[6] D. Held, "Democracy and globalization," in Re-imagining Political Community, D. Archibugi, D. Held, and M. K. Stanford, Ed. California: Stanford University Press, 1998, pp. 11-27.

[7] J. A. Scholte, "Global capitalism and the state," International Affairs, vol. 73, no. 3, pp. 427-452, July 1997.

[8] H. Kosebalaban, "The impact of globalization on Islamic political identity: The case of Turkey," World Affairs, vol. 168, no. 1, pp. 27-37, Summer 2005.

[9] K. Woodward, Identity and Difference, London: Sage, 1997, pp. 12-18.

[10] J. G. Herder, J. G. Herder on Social and Political Culture, Cambridge: Cambridge University Press, 1969, pp. 17-32.

[11] R. Poole, Nation and Identity, London: Routledge, 1999, pp. 68.

[12] L. Balthazar, "Quebec and the ideal of federalism," in Quebec Society: Critical Issues, M. Fournier, M. Rosenberg, and D. White. Ed., Scarborough: Prentice Hall, 1997, pp. 45-60.

[13] F. J. Fletcher. (1998). Media and political identity: Canada and Quebec in the era of globalization. Canadian Journal of Communication. [Online]. 23(3). Available: http://www.cjc-online.ca/index.php/journal/article/view/1049/955

[14] M. Charland, "Technological nationalism," Canadian Journal of Social and Political Theory, vol. 10, no. 1-2, pp. 196-220, 1986.

[15] P. Audley. (1994). Cultural industries policy: Objectives, formulation, evaluation. Canadian Journal of Communication. [Online]. 19(3-4). Available: http://cjc-online.ca/index.php/journal/article/view/823/729

[16] R. Falk, "False universalism and the geopolitics of exclusion: The case of Islam," Third World Quarterly, vol. 18, no. 1, pp. 7-23, 1997.

[17] I. D. Dagi, "Rethinking human rights, democracy, and the west: post-Islamist intellectuals in Turkey," Critique: Critical Middle Eastern Studies, vol. 13, no. 2, pp. 135-151, 2004.

[18] Erdogan dan Iran a Dunyaya Açilin Cagrisi, Erdogan Calls on Iran to Open Itself to the World, Zaman, July 30, 2004,

[19] H. Kosebalaban, "The impact of globalization on Islamic political identity: The case of Turkey," World Affairs, vol. 168, no. 1, pp. 27-37, Summer 2005. 
Hao Zhang was born in Beijing, China on $07^{\text {th }}$ Jan. 1988. She got Master of Science in Media and Communications Research (University of Leicester, Leicester, Leicestershire, UK. $27^{\text {th }}$ Jan. 2012). Her major field of study is research methods in social science, managing and communication research, international communication. And she got Bachelor of Arts in the Specialty of Journalism (Beijing International Studies University, Beijing, China. $23^{\text {rd }}$ Jun. 2010). From
October to December in 2012, she worked as a Researcher Intern in Horizon Research Consultancy Group. From February till now, she has worked as a News Editor in Social Sciences in China Press (Taida Building, Chaoyang District, Beijing, 100026, China). Her previous publication is "Zhou Lianxuan, Li Mao, Zhang Hao, Su Minsi, Bai Yu, Zhang Yan, Report on the way of University Student's Time Managing. Journal of Beijing International Studies University, supplementary issue, Jun. 2008." Her research interest is international communication, media and conflict resolution. 